Volume 11, Nomor 2, November 2019, pp 199-210 Copyright (C) 2017 Jurnal Akuntansi Maranatha, Program Studi Akuntansi, Fakultas Ekonomi, Universitas Kristen Maranatha. ISSN 2085-8698 | e-ISSN 2598-4977. http://journal.maranatha.edu

\title{
Analisis Potensi Kecurangan Dalam Pengelolaan Keuangan Desa (Studi: Desa Kesongo, Kecamatan Tuntang, Kabupaten Semarang, Jawa Tengah)
}

\author{
Ismail Alfaruqi \\ Fakultas Ekonomika dan Bisnis Program Studi Akuntansi-Univ.Kristen Satya Wacana \\ (Jl. Diponegoro No. 52-60, Salatiga) \\ 232015047@student.uksw.edu \\ Ika Kristianti \\ Fakultas Ekonomika dan Bisnis Program Studi Akuntansi-Univ.Kristen Satya Wacana \\ (Jl. Diponegoro No. 52-60, Salatiga) \\ ika.kristianti@staff.uksw.edu
}

\begin{abstract}
Indonesia Corruption Watch (ICW) found 154 corruption cases during 2015-2017, most of them were corruption cases involving the village budget. The potential for fraud can be detected by cheating triangle theory, namely pressure, opportunity and rationalization. The purpose of this study is to identify potential fraud in village financial management. This study uses a qualitative approach and the type of data used is primary data obtained directly using interview techniques from the village financial management process conducted by the Village Financial Management Technical Officer (PTPKD) Kesongo Village, Tuntang District, Semarang Regency. The results of the study show that in the village financial management in Kesongo Village there is potential for fraud including: the necessity to do something; disciplinary behavior; feel that they are not detrimental to others and consider mistakes to be natural and often occur. This study concluded that in Kesongo Village there was potential for fraud in the process of village financial management.
\end{abstract}

Keywords: Village Financial Management, Village Apparatus, Potential for Fraud, Control

\section{Pendahuluan}

Pelaksanaan Anggaran Pendapatan dan Belanja Desa (APBDes) memiliki peran penting dalam kesuksesan pembangunan daerah. APBDes merupakan perwujudan dari pertanggungjawaban,kemampuan dan kinerja pemerintah desa dalam melaksanakan proses pengelolaan keuangan desa. Pada realisasinya masyarakat sering mengeluhkan proses alokasi anggaran yang tidak selaras dengan skala prioritas kebutuhan dan hanya sedikit 
merepresentasikan segi efektivitas, efisiensi dan ekonomi (Mardiasmo dalam Hehanussa, 2015).

\section{Indonesia Corruption Watch} (ICW, 2018) telah mengawasi tindakan korupsi yang terjadi di desa. Hasil pemantauan ICW, pada tahun $2015-2017$ kasus tindak pidana korupsi di desa semakin meningkat. Kasus korupsi mencapai 17 kasus pada tahun 2015 dan melonjak menjadi 41 kasus pada tahun 2016. Peningkatan yang sangat signifikan terjadi di tahun 2017 dengan 96 kasus. Sehingga seluruh kasus korupsi yang teridentifikasi berjumlah 154 kasus.

Dari 154 kasus korupsi tersebut, tidak semuanya adalah kasus korupsi yang melibatkan APBDes. Jumlah kasus dengan objek APBDes berjumlah 127 kasus, sementara berturut-turut terdapat 27 kasus dengan objek bukan anggaran desa atau total $18 \%$ dari jumlah kasus. Pemungutan liar yang dilakukan aparat desa merupakan kasus dengan objek selain APBDes. Sedangkan kasus terkait APBDes yang dikorupsi terdiri dari korupsi Alokasi Dana Desa (ADD), Dana Desa, Kas Desa dan lain-lain.

Bermacam-macam modus dilakukan oleh pelaku korupsi di pemerintahan desa, sebagian besar merupakan praktik penyalahgunaan anggaran sebanyak 51 kasus, 32 kasus penggelapan, laporan fiktif dengan 17 kasus, kegiatan atau proyek fiktif 15 kasus dan sebanyak 14 kasus pembengkakkan anggaran. Melonjaknya korupsi di sektor desa menggambarkan catatan buruk yang berkaitan eratdengan pembahasan evaluasi kebijakan pemerintah untuk desa. Seluruh kasus korupsi tersebut mensyaratkan bahwa desa yang diyakini menjadi bagian dari pembangunan sampai detik ini menjadi ladang korupsi yang baru.

APBDes yang dikorupsi dan disalahgunakan akan memberikan pengaruh sangat negatif bagi harapan meningkatnya kesejahteraan masyarakat desa dan pembangunan desa. Tingkat kemiskinan tidak mengalami penurunan yang signifikan terhitung setelah tiga tahun implementasi kebijakan pemerintah untuk mendukung keuangan desa bersumber dari APBN. Badan Pusat Statistik (BPS), menyatakan pada bulan September 2016 tingkat angka kemiskinan melonjak sampai 27,76 juta orang dan menjadi 27,77 juta orang pada bulan Maret 2017.

Fenomena penyalahgunaan keuangan desa menimbulkan kegundahan bagi masyarakat dan pemerintah secara umum, karena jika dianalisis lebih mendalam sebenarnya pemerintah telah menetapkan berbagai aturan dan pedoman terkait keuangan desa dengan harapan proses pelaksanaan pengelolaan keuangan desa dapat mudah dilaksanakan agar tidak memunculkan kecurigaan dan bahkan menimbulkan potensi kecurangan dalam pelaksanaannya. Tata kelola keuangan desa yang efisien dan efektif dengan asas akuntabilitas, transparansi dan partisipatif diharapkan dapat tercipta.

Proses dan tata cara penyusunan APBDes yang diatur dalam Peraturan Menteri Dalam Negeri Nomor 37 Tahun 2007 tentang Pedoman Pengelolaan Keuangan Desa memberikan penjelasan seputar tanggung jawab yang berkaitan dengan pengelolaan keuangan desa di setiap aparat desa. Selain itu, status desa sebagai pemerintahan masyarakat dan sarana untuk memajukan serta memberdayakan masyarakat desa diperkuat dalam Undang Undang Nomor 6 Tahun 2014 tentang Desa. Sanjiwani (2015) mengungkapkan bahwa otonomi daerah mampu menyumbangkan keuntungan dengan meluruskan alokasi sumber daya cipta lewat perpindahan menuju ke tingkat pengambilan keputusan pemerintah yang lebih rendah.

Penelitian berkaitan dengan teori kecurangan yang dilakukan oleh Suprajadi dalam Putri \& Wahyono (2018) menyatakan bahwa penipuan (deception), kepercayaan (confidence), tipu daya (trickery) dan strategi penyembunyian 
(concealment strategy) merupakan komponen dari kecurangan. Kecakapan aparatur dan sistem pengendalian internal sangat mempengaruhi pencegahan kecurangan pengelolaan keuangan desa (Atmadja \& Saputra, 2017). Rahman, Suwandi \& Hamid (2016) serta Yulianah (2015) melakukan penelitian terkait potensi penyalahgunaan pengelolaan keuangan alokasi dana desa. Sedangkan hasil dari penelitian lain menunjukkan pengelolaan keuangan desa di Indonesia memiliki potensi kecurangan yang cukup mengkhawatirkan di setiap prosesnya (Walukow, Kalangi, \& Piantik, 2017) serta (Seputro, Wahyuningsih, \& Sunrowiyati, 2017). Penerapan pengelolaan keuangan desa di Indonesia merupakan program baru pemerintah sebagai perwujudan otonomi daerah, sehingga belum banyak penelitian yang dilakukan terutama penelitian berkaitan dengan kecurangan pengelolaan keuangan desa.

Seluruh desa-desa di Indonesia diharapkan dapat menerapkan aplikasi sistem keuangan desa (siskeudes) sebagai pengembangan teknologi untuk mencegah terjadinya kecurangan-kecurangan yang tidak diinginkan. Aplikasi siskeudes mengubah sistem pelaporan yang masih manual dan kurang efektif menjadi terotomatisasi dan lebih efektif. Desa Kesongo sudah menerapkan sistem yang baru namun sistem lama atau manual masih tetap digunakan. Desa Kesongo yang terletak di Kecamatan Tuntang, Kabupaten Semarang ini merupakan salah satu desa yang telah mampu menerapkan siskeudes dengan baik sejak awal tahun 2017.

Dari latar belakang kasus penyalahgunaan pengelolaan keuangan desa yang semakin banyak, peneliti menganggap perlu adanya sebuah penelitian berkaitan dengan potensi kecurangan di Desa Kesongo, Kecamatan Tuntang, Kabupaten Semarang yang telah mampu menerapkan Siskeudes sebagai instrumen pengelolaan keuangan desa. Penelitian ini diharapkan mampu menurunkan rasa cemas pihak - pihak terkait, diantaranya adalah aparat desa yang kurang pemahaman, pengetahuan dan kemampuan dalam mengelola keuangan desa sehingga bermasalah dengan aparat hukum.

Penelitian ini memiliki persoalan yaitu: apakah terjadi adanya potensi kecurangan berkaitan dengan pengelolaan keuangan desa di Desa Kesongo? Adapun tujuan dari penelitian ini adalah untuk mengidentifikasi adanya potensi kecurangan pengelolaan keuangan desa di Desa Kesongo, Kecamatan Tuntang, Kabupaten Semarang. Objek ini dipilih karena pendapatan transfer dalam APBDes Desa Kesongo pada tahun 2018 berjumlah Rp 1.652.129.000, -. Angka tersebut merupakan pendapatan transfer terbesar kedua di antara desa - desa di Kecamatan Tuntang, Kabupaten Semarang setelah Desa Candirejo. Sehingga dalam pelaksanaan operasional Desa Kesongo dimungkinkan terjadi penyalahgunaan maupun tindak kecurangan yang dilakukan oleh pihakpihak pengelola keuangan desa tersebut

Penelitian diharapkan dapat menganalisis potensi kecurangan pada pengelolaan keuangan desa di Desa Kesongo, Kecamatan Tuntang, Kabupaten Semarang, serta menghindari terjadinya penyalahgunaan dan tindak kecurangan oleh pihak-pihak pengelola keuangan desa. Bagi Badan Pengawasan Keuangan Pembangunan (BPKP), penelitian memberi kontribusi potensi kecurangan terhadap penggunaan pengelolaan keuangan desa dalam proses perencanaan, pelaksanaan dan pertanggungjawaban. Bagi civitas akademika akuntansi, penelitian memberi kajian di bidang auditing tentang potensi kecurangan pada pengelolaan keuangan desa serta memberi pengetahuan lebih bagi masyarakat Desa Kesongo, Kecamatan Tuntang, Kabupaten Semarang mengenai potensi kecurangan pengelolaan keuangan desa, sehingga masyarakat dapat ikut mengawasi dan mencegah kecurangan pengelolaan keuangan desa. 


\section{Kerangka Teoritis}

\section{Desa dan Pemerintahan Desa}

Menurut Peraturan Menteri Dalam Negeri Nomor 113 Tahun 2014, desa dan desa adat atau yang disebut dengan nama lain, selanjutnya disebut Desa, adalah kesatuan masyarakat hukum yang memiliki batas wilayah yang berwenang untuk mengatur dan mengurus urusan pemerintahan, kepentingan masyarakat setempat berdasarkan prakarsa masyarakat, hak asal usul dan/atau hak tradisional yang diakui dan dihormati dalam sistem pemerintahan Negara Republik Indonesia.

Pengertian universal dari desa yaitu salah satu keadaan yang bersifat umum, terdapat di dunia ini, sebagai suatu komunitas kecil, yang terikat pada lokalitas tertentu baik sebagai tempat tinggal maupun bagi pemenuhan kebutuhannya dan memiliki ketergantungan utama pada sektor pertanian (Rahardjo dalam Abidin, 2015).

Menurut Peraturan Menteri Dalam

Negeri Nomor 113 tahun 2014, Pemerintahan Desa adalah penyelenggaraan urusan pemerintahan dan kepentingan masyarakat setempat dalam sistem pemerintahan NKRI. Pemerintah Desa adalah kepala desa atau sebutan lainnya dibantu perangkat desa sebagai unsur peyelenggaraan pemerintah desa.

\section{Pengelolaan Keuangan Desa}

Menurut Peraturan Menteri Dalam Negeri Nomor 113 tahun 2014, keuangan desa adalah semua hak dan kewajiban desa yang dapat dinilai dengan uang serta segala sesuatu berupa uang dan barang yang berhubungan dengan pelaksanaan hak dan kewajiban desa. Pengelolaan Keuangan Desa adalah keseluruhan kegiatan yang meliputi perencanaan, pelaksanaan, penatausahaan, pelaporan dan pertanggungjawaban keuangan desa.

Menurut Peraturan Menteri Dalam Negeri Nomor 113 Tahun 2014 tentang Pengelolaan Keuangan Desa. Keuangan desa dikelola berdasarkan asas-asas transparan, akuntabel partisipatif, serta dilakukan dengan tata tertib dan disiplin anggaran. Pengelolaan keuangan desa, dikelola dalam masa satu tahun anggaran yakni mulai tanggal 1 Januari sampai dengan tanggal 31 Desember. Pengelolaan keuangan desa tidak lepas dari Kepala Desa dan perangkat Desa lainnya.

\section{Kecurangan}

Albrect, Alberct, Alberct dan Zimbelman (2011) mendefinisikan fraud sebagai segala cara yang dirancang oleh kecerdikan manusia untuk merugikan orang lain dengan penyajian yang tidak sesuai. Belum ada pedoman yang bersifat universal dalam mendefinisikan fraud karena fraud merupakan kejutan, penipuan, kelicikan dan berbagai macam cara untuk mencurangi pihak lain. Kecurangan adalah pembohongan yang menyebabkan keuntungan bagi pelaku tanpa disadari oleh korban yang dirugikan dan dilakukan dengan sengaja.

Tiga elemen kecurangan yang diringkas oleh Cressey dalam Ratmono, Diany \& Purwanto (2017) biasanya disajikan dalam diagram yang ditunjukkan di bawah ini. Elemen atas diagram mewakili tekanan atau motif untuk melakukan tindakan kecurangan sementara dua elemen di bagian bawah adalah kesempatan yang dan rasionalisasi (Wells, 2011). Selama bertahun-tahun, hipotesis kecurangan yang dipicu oleh Cressey telah dikenal sebagai teori segitiga kecurangan.

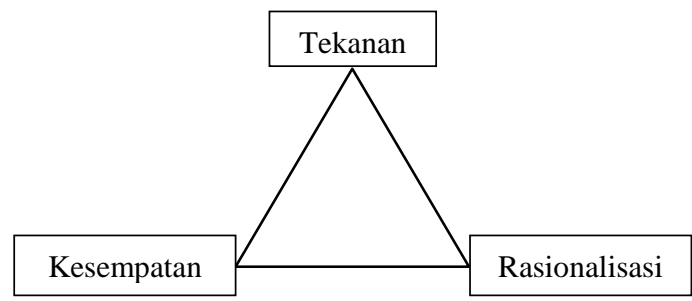

Tekanan atau insentif yang dirasakan terkait dengan motivasi yang mengarah pada tindakan non-etis. Bermacam - macam jenis tekanan yang 
dapat mendorong tindakan menyimpang dihadapi oleh seluruh pelaku. Penelitian Lister (2007) mengungkapkan faktor yang paling relevan dalam melakukan penyelewengan adalah tekanan. Unsur penting terjadinya kecurangan yang kedua adalah kesempatan. Kesempatan terjadi karena tidak efektifnya sistem pengendalian yang menyebabkan tindak kecurangan oleh seseorang. Suatu individu akan menggunakan kesempatan yang ada sebaik mungkin (Kelly \& Hartley, 2010).

Rasionalisasi merupakan unsur ketiga dalam segitiga kecurangan. Pelaku harus memperkuat bahwa tindakan non-etis yang dilakukannya merupakan hal benar yang dapat diterima secara umum. Rasionalisasi mengarah ke argumen bahwa tindakan non-etis yang dilakukan bukanlah aksi kejahatan. Tidak mudah untuk mendeteksi rasionalisasi, karena apa yang ada di dalam pikiran pelaku mustahil untuk dibaca (Ratmono, Diany, \& Purwanto, 2017). Pelaku kecurangan memiliki pola berpikir masing-masing yang membuat tindakan mereka benar dan dapat dimaafkan (Hooper \& Pornelli, 2014)

\section{Metode Penelitian}

\section{Desain Penelitian}

Penelitian ini menggunakan pendekatan kualitatif, untuk mengeksplorasi fenomena atau gejala sosial yang terjadi. Penelitian ini merupakan penelitian deskriptif dengan metode observasi dan wawancara mendalam (indepth interview), untuk memberi gambaran potensi kecurangan dalam pengelolaan dana desa. Narasumber penelitian adalah Pelaksana Teknis Pengelolaan Keuangan Desa (PTPKD) atau aparat desa yang bertanggung jawab pada pengelolaan dana desa di Desa Kesongo yang berjumlah enam orang sesuai dengan surat keputusan tahun 2018. PTPKD terdiri dari satu Kepala Desa, satu Sekretaris Desa, satu Bendahara Desa atau Kepala Urusan (KAUR) Keuangan, tiga Kepala Seksi
(KASI) yaitu KASI Pemerintahan, KASI Kesejahteraan dan KASI Pelayanan. Aparat desa tersebut akan menjawab pertanyaanpertanyaan yang diajukan oleh peneliti.

Pertanyaan berupa pertanyaan terbuka terkait pengelolaan keuangan desa dan aspek kecurangan yang terjadi di dalamnya. Pada pengelolaan keuangan desa, pertanyaan yang diajukan berupa bagaimana prosedur pengelolaan dana desa serta hal-hal apa saja yang dilaporkan dalam pengelolaan keuangan desa. Sedangkan dalam aspek kecurangan, pertanyaan yang diajukan mengenai indikator-indikator dari konsep segitiga kecurangan meliputi tekanan, kesempatan dan rasionalisasi yang mendorong terjadinya tindakan kecurangan serta penyelewengan pengelolaan keuangan desa.

\section{Objek Penelitian}

Penelitian ini menggunakan objek pengelolaan keuangan desa oleh aparat desa Desa Kesongo, Kecamatan Tuntang, Kabupaten Semarang.

\section{Data dan Sumber Data}

Penelitian ini menggunakan data primer yang didapatkan langsung dari sumber otentik berupa pendapat seorang atau lebih individu. Data didapatkan secara langsung dari Pelaksana Teknis Pengelolaan Keuangan Desa (PTPKD) Desa Kesongo, Kecamatan Tuntang, Kabupaten Semarang. Koordinator PTPKD merupakan narasumber utama dalam penelitian ini. Narasumber dipilih sebagai sumber data berdasarkan peran serta dalam pengolahan keuangan desa, kelengkapan keterangan dan keakuratan informasi yang diberikan.

\section{Teknik Pengumpulan Data}

Teknik wawancara dan observasi digunakan untuk mendapatkan data dalam penelitian ini. Wawancara langsung dan observasi dengan PTPKD serta proses pengelolaan keuangan desa Desa Kesongo untuk mendapatkan kebutuhan data: 
1. Data tentang gambaran umum Desa Kesongo, Kecamatan Tuntang, Kabupaten Semarang.

2. Data tentang Pelaksana Teknis Pengelolaan Keuangan Desa (PTPKD).

3. Data tentang pengelolaan keuangan desa.

4. Data tentang prosedur pengelolaan keuangan desa.

5. Data tentang potensi kecurangan dalam pengelolaan keuangan desa.

\section{Teknik Analisis}

Penelitian menggunakan data primer yang diperoleh dengan menggunakan teknik wawancara dan observasi. Penelitian ini menggunakan teknik analisis deskriptif kualitatif, yaitu memberi gambaran dan deskripsi mengenai karakteristik narasumber. Penelitian dimulai dari peneliti mengajukan pertanyaan terbuka kepada narasumber. Setelah dilakukan analisis data, hasil jawaban narasumber diolah dan disajikan dalam bentuk data. Pertanyaan terbuka dalam wawancara digunakan untuk menggali informasi lebih dalam tentang pengelolaan keuangan desa, serta potensi kecurangan yang terjadi di dalamnya.

\section{Hasil Penelitian dan Pembahasan}

\section{Gambaran Umum Desa Kesongo, Kecamatan Tuntang, Kabupaten Semarang \\ Desa Kesongo merupakan salah satu desa} yang terletak di Kecamatan Tuntang, Kabupaten Semarang, Jawa Tengah, Indonesia. Batas wilayah geografis Desa Kesongo di sebelah timur terdapat Desa Watuagung, sebelah selatan Desa Candirejo, sebelah barat berbatasan dengan Rawa Pening dan utara berbatasan dengan Desa Lopait. Desa Kesongo mempunyai tanah yang cukup subur dan hawa yang sejuk. Luas wilayah Desa Kesongo, Kecamatan Tuntang, Kabupaten Semarang secara keseluruhan sebesar 426,428 Ha. Secara administratif, Desa Kesongo terdiri dari 7 Dusun, 8 RW dan 47 RT. 7 dusun yang tergabung dalam Desa Kesongo yaitu Dusun Krajan, Dusun Ngentaksari, Dusun Kesongkor, Dusun Ngreco, Dusun Sejambu, Dusun Widoro dan Dusun Banjaran. Berdasarkan Sistem Terpadu Administrasi Data Desa (SMART DESA) total jumlah penduduk 8.184 jiwa yang terdiri dari penduduk berjenis kelamin perempuan 4.122 jiwa, laki-laki 4.062 jiwa dengan kepala keluarga 2.179.

Struktur organisasi Desa Kesongo, terdiri dari Kepala Pemerintahan Desa yang dipimpin oleh seorang Kepala Desa dibantu oleh Sekretaris Desa yang bertugas membantu Kepala Desa dalam bidang administrasi pemerintahan. Sekretaris Desa membawahi Kepala Urusan (Kaur) Umum dan Perencanaan serta Bendahara Desa sebagai Kaur Keuangan yang mengurusi administrasi keuangan. Selain itu terdapat juga 3 (tiga) Kepala Seksi (Kasi) yang terdiri dari Kasi Pemerintahan yang melaksanakan manajemen tata pemerintahan, Kasi Kesejahteraan yang melaksanakan pembangunan sarana dan prasarana pedesaan serta Kasi Pelayanan yang melaksanakan penyuluhan dan motivasi terhadap pelaksanaan hak dan kewajiban masyarakat. Untuk menunjang kegiatan operasional dan pelaksanaan monitoring pelaksanaan kegiatan dan keuangan, Desa Kesongo diawasi oleh Badan Permusyawaratan Desa (BPD).

\section{Potensi Kecurangan}

Potensi kecurangan yang dapat ditemukan dalam proses pembangunan dan penyusunan pelaporan keuangan misalnya pemalsuan, manipulasi data atau mengubah dokumen-dokumen pendukung dalam menyusun laporan keuangan. Dalam mengelola keuangan, aparat desa harus membuat pelaporan yang harus dilaporkan sesuai dengan tenggat waktu. Konsekuensi yang didapatkan jika pengelolaan keuangan desa tidak dilakukan sesuai dengan prosedur adalah timbulnya masalah seperti penyusunan APBD Desa tahun berikutnya 
akan terhambat. Hal ini sesuai yang diungkapkan oleh narasumber,

"Ya, untuk SPJ APBDes maksimal
tanggal 10 Januari tahun berikutnya,
setelah SPJ selesai, terdapat
pengumpulan data awal yang disebut
LRA. Jika ada salah satu kegiatan
yang belum selesai SPJ, maka LRA
tidak bisa dicetak dan belum bisa
disampaikan ke BPK. LRA yang belum
tercetak akan mengganggu siklus
pengelolaan keuangan desa seperti
penyusunan, APBDes tahun
berikutnya."

Kesempatan untuk melakukan kecurangan dapat timbul karena adanya celah dalam lemahnya pengendalian untuk mencegah dan mendeteksi pelanggaran. Desa Kesongo memiliki SOP seperti jadwal pelayanan kantor dan pemisahan tugas yang sudah ditetapkan oleh Peraturan Bupati sehingga dapat mencegah terjadinya kecurangan. SOP tersebut telah dijalankan walaupun belum dipenuhi secara menyeluruh. Hal ini sesuai yang diungkapkan oleh narasumber,

"Terdapat regulasi pelayanan jam
kantor pemerintahan desa dari Surat
Edaran Bupati yaitu jam 08:00 sampai
jam 15:00 setiap hari Senin sampai
dengan Kamis dan jam 08:00 sampai
jam 11:30 untuk hari Jumat, terkait
presensi teman - teman memang kita
kadang kontrolnya belum begitu kuat.
Mau kaku dengan aturan juga tidak
bisa, misalkan teman - teman hadir
08:30 atau jam 09:00 itu betul
datangnya jam saat itu tetapi secara
aturan kan tidak sesuai Surat Edaran
Bupati. Jadi SEB jam 8-15 itu ya kita
penuhi tetapi belum semua itu
memenuhi."

Sekretaris Desa selaku koordinator PTPKD melakukan pemeriksaan di setiap pekerjaan PTPKD walaupun tidak diperiksa secara menyeluruh. Hal ini sesuai yang diungkapkan oleh narasumber,

"Tidak tahu sepenuhnya tetapi sampai 75\% telah saya crosscheck beberapa sampel. Misal bulan ini, saya sudah mengeluarkan uang berapa, yang belum ter SPJ itu apa, saya harus tahu. Saya tahu aliran dana dari laporan bendahara, dari bendahara baru saya tanyakan kepada kasir secara rinci."

Kelalaian aparat desa dalam melaksanakan pengelolaan keuangan desa dapat merugikan pihak lain. Salah satu pihak yang dirugikan karena terjadi sebuah kelalaian oleh aparat desa adalah kelompok masyarakat. Dana kelompok masyarakat digunakan untuk menutupi pungutan pajak. Hal ini sesuai dengan yang diungkapkan narasumber,

"Temuan terakhir kami hanya
masalah salah persepsi saya tentang
pemungutan pajak yang kemarin
menjadi laporan hasil pemeriksaan
oleh APIP karena kita tidak tahu cara
pemungutan pajak yang benar, kita
dapat uang untuk menutupi PPN dari
dana kelompok masyarakat atau
TPK."

Kecurangan dapat timbul karena kesalahan atau pelanggaran tersebut merupakan hal yang biasa dan sering terjadi. Desa Kesongo menganggap bahwa kesalahan dalam administrasi adalah hal yang wajar. Hal ini sesuai dengan yang diungkapkan narasumber,

"Kalau masalah administrasi itu
barang lumrah, orang lupa misalkan
sudah dibuatkan SPJ tapi kebetulan
salah penempatan atau salah buku
hingga hilang itu barang lumrah."

Pengendalian internal yang baik dapat mencegah terjadinya potensi kecurangan. Pemberian sanksi terhadap tindakan yang menyimpang merupakan salah satu contoh pencegahan kecurangan. Pimpinan Desa Kesongo akan memberikan sanksi terhadap perilaku menyimpang. Hal ini sesuai dengan yang diungkapkan narasumber,

"Tahapan dari teguran lisan 123, tertulis 123 sampai SP 123 itu ada ketentuan ketentuannya, yang paling fatal itu menyangkut masalah keuangan, pencemaran nama baik 
desa, atau mungkin YBS terkena perkara pidana itu sudah masuk perintah pelanggaran - pelanggaran berat."

Dari hasil wawancara tersebut dapat diketahui bahwa pernyataan para narasumber mengindikasikan adanya potensi kecurangan seperti keharusan untuk melakukan sesuatu, indisipliner, kelalaian terhadap pembayaran pungutan pajak yang merasa tidak merugikan pihak lain dan menganggap kesalahan adalah hal yang wajar dan sering terjadi. Di samping itu, aparat Desa Kesongo memiliki pengendalian internal yang baik untuk mencegah tindakan kecurangan dan kepercayaan bahwa sampai saat ini tidak ada niat untuk melakukan tindakan kecurangan. Oleh karena itu, aparat Desa Kesongo bekerja dengan bersih tanpa adanya tindakan menyimpang atau kecurangan, hal ini dibuktikan dengan prestasi yang didapatkan berupa Juara Harapan II Desa Hebat di Kabupaten Semarang.

\section{Pembahasan}

Berdasarkan hasil penelitian yang telah dilakukan di Desa Kesongo, Kecamatan Tuntang, Kabupaten Semarang, terdapat potensi kecurangan dalam proses pengelolaan keuangan desa. Potensi kecurangan tersebut dapat timbul karena faktor tekanan yang dirasakan, kesempatan dan rasionalisasi. Ketiga faktor potensi kecurangan tersebut berkaitan dengan keharusan PTPKD untuk melakukan sesuatu, melakukan tindakan indisipliner, merasa tidak ada pihak yang dirugikan dalam melakukan kelalaian dan membenarkan kesalahan yang sering terjadi. Sementara itu aparat Desa Kesongo, Kecamatan Tuntang, Kabupaten Semarang mempunyai pencegahan tindak kecurangan berupa sanksi teguran sampai hukum pidana dan mereka yakin bahwa sampai saat ini tidak ada niat untuk melakukan tindakan kecurangan dalam pengelolaan keuangan desa.
Desa Kesongo memiliki pengendalian internal yang cenderung masih kurang untuk mencegah upaya penyimpangan atau pelanggaran oleh PTPKD. Selain itu, koordinator PTPKD belum melakukan pemeriksaan terhadap proses pengelolaan keuangan desa yang dilakukan oleh Kasi dan Kaur di bawahnya secara menyeluruh. Pengendalian internal yang lemah dan pemeriksaan yang kurang untuk mencegah dan mendeteksi tindakan kecurangan dapat timbul peluang yang luas bagi aparat desa untuk melancarkan aksi kecurangan. Dengan adanya struktur pengendalian internal yang kuat, aktivitas pengendalian yang optimal dan peran internal audit yang efektif akan dapat mencegah kecurangan (Kartini, 2018).

Tindakan indisipliner adalah salah satu potensi kecurangan yang terdapat dalam proses pelaksanaan pengelolaan keuangan desa. Indisipliner yang dimaksud adalah aparat desa melakukan penyimpangan aturan dari Surat Edaran Bupati (SEB). Aturan tersebut ada namun tidak dijalankan sepenuhnya oleh aparat desa karena absensi kantor Desa Kesongo masih menggunakan absensi manual. Potensi kecurangan tersebut muncul dari kurangnya upaya pengendalian yang diterapkan oleh aparat Desa Kesongo. Hal ini selaras dengan penelitian Albrecht et al. (2012) timbulnya kesempatan disebabkan karena pengendalian untuk mencegah upaya penyimpangan yang kurang. Upaya pengendalian yang tepat untuk dilakukan adalah dengan menggunakan sistem absensi finger print. Penelitian Lahinta, Sudirman, \& Kadri (2018) membuktikan bahwa sistem absensi finger print dapat meningkatkan tingkat kedisiplinan pegawai secara signifikan dari $7,5 \%$ menjadi $88,1 \%$. Selain itu diperlukan pengendalian berupa pembinaan Sumber Daya Manusia (SDM) untuk mematuhi SOP Kepegawaian (Mujennah \& Artinah, 2018).

Hasil dari wawancara yang dilakukan di Desa Kesongo menunjukkan bahwa terdapat potensi kecurangan di mana 
kesalahan dianggap wajar dan sering terjadi di lingkup internal aparat desa. Potensi kecurangan tersebut timbul karena sifat rasionalisasi pelaku yang menganggap wajar kesalahan dan pengawasan yang kurang. Pelaku kecurangan melakukan kecurangan karena sikap mereka yang menganggap wajar terhadap kecurangan yang mereka lakukan (Kurniawan, 2013). Kecurangan yang dilakukan di lingkup internal yang pengawasannya kurang memiliki kecenderungan tinggi untuk melakukan kecurangan lebih dari satu kali (Suprajadi dalam Udayani \& Sari, 2017). Potensi kecurangan tersebut terjadi dalam tahap pertanggungjawaban pengelolaan keuangan desa. Kesalahan yang sering terjadi dan dianggap wajar adalah kesalahan dalam hal administratif seperti penyusunan laporan pertanggungjawaban (LPJ) yang salah dan dokumen pendukung laporan yang kurang. Hal ini tidak dibenarkan dalam Peraturan Menteri dalam Negeri No. 20 Tahun 2018 tentang Pengelolaan Keuangan Desa, di mana lampiran atau dokumen-dokumen pendukung harus disertakan sesuai Peraturan Menteri. Pengendalian untuk mencegah potensi kecurangan ini adalah dengan meningkatkan nilai moral dan etika dari seluruh aparat desa agar lebih berintegritas. Aparat desa diharapkan dapat memiliki integritas yang baik dan tidak membenarkan tindakan kecurangan yang dilakukan dengan perubahan moral dan etika yang meningkat (Aksa, 2018).

Potensi kecurangan selanjutnya adalah kelalaian yang secara tidak sadar dilakukan oleh aparat desa akan merugikan pihak lain. Kecurangan cenderung terjadi karena sikap pelaku yang melakukan kesalahan sembari merugikan pihak lain atau organisasi (Rosyadi, Soebagyo, \& Suyatmin, 2016). Pada tahap pelaksanaan pengelolaan keuangan desa oleh Kaur Keuangan, beliau lalai dalam pembayaran pajak karena kurang paham mengenai pembayaran pajak sehingga aparat desa harus menutupi kekurangan pembayaran tersebut menggunakan dana dari kelompok masyarakat. Hal ini tentunya tidak sesuai dengan Peraturan Menteri Dalam Negeri No. 20 Tahun 2018 tentang Pengelolaan Keuangan Desa, seluruh pungutan pajak wajib disetorkan ke rekening kas negara sesuai dengan ketentuan peraturan perundang-undangan oleh Kaur Keuangan. Koordinator PTPKD seharusnya memberikan pengendalian internal berupa pembinaan lebih intensif terhadap aparat desa yang kurang paham mengenai aturan terkait pengelolaan keuangan desa dan menyiapkan dana penambahan agar tidak merugikan pihak lain. Hal ini senada dengan penelitian Hermawan (2017) di mana aparat desa yang kurang paham aturan pembayaran pajak sebesar $6 \%$ dapat dicegah dengan meningkatkan pengetahuan SDM serta melengkapi sarana penunjang sosialisasi dan penambahan dana.

Selain itu, potensi kecurangan yang terdapat di Desa Kesongo adalah tekanan yang dirasakan dari keharusan untuk melakukan sesuatu. Seorang individu akan merasakan tekanan yang besar dari paksaan atau keharusan untuk menyelesaikan pekerjaan sebaik mungkin (Cizex, 2010). Hal ini sejalan dengan hasil penelitian yang menunjukkan bahwa aparat desa diharuskan untuk menyusun laporan sesuai dengan prosedur. Prosedur yang dimaksud adalah Peraturan Menteri Dalam Negeri No. 20 Tahun 2018 tentang Pengelolaan Keuangan Desa. Aparat desa diharuskan untuk mematuhi prosedur tersebut seperti menyusun laporan pertanggungjawaban sesuai tenggat waktu, sehingga menyebabkan timbulnya kecurangan seperti menggunakan dokumen pendukung yang palsu untuk segera menyelesaikan laporan sesuai pada waktu yang sudah ditentukan. Dampak dari LPJ yang tidak tepat waktu adalah terhambatnya proses penyusunan APBDes tahun berikutnya. Pengendalian yang baik untuk mencegah potensi kecurangan tersebut adalah dengan menghilangkan tekanan itu sendiri dengan menegakkan aturan hukum. 
Pemberian sanksi atau hukuman atas pemalsuan dokumen, penundaan gaji dan sanksi lainnya sesuai ketentuan peraturan perundang-undangan yang berlaku dapat mencegah tekanan yang menimbulkan kecurangan (Aksa, 2018).

Penelitian Wijayanti \& Hanafi (2018) menunjukkan keharusan pihak pimpinan aparat desa untuk melakukan pembinaan dalam peningkatan moralitas diri dan mempertegas peraturan untuk mencegah terjadinya fraud. Hal ini sesuai dengan upaya aparat desa untuk mencegah dan mendeteksi kecurangan dalam pengelolaan keuangan desa, aparat Desa Kesongo bertindak tegas terhadap perilaku menyimpang dengan pemberian sanksi berupa teguran lisan, teguran tertulis, surat peringatan dan apabila terjadi kesalahan yang fatal seperti masalah keuangan dan pencemaran nama baik desa maka akan diberi hukuman pidana. Meskipun absensi masih manual dan aturan SEB tidak dilaksanakan secara kaku, pimpinan Desa Kesongo percaya bahwa tidak ada niat aparat PTPKD untuk melakukan tindakan kecurangan.

\section{Simpulan dan Saran}

\section{Simpulan}

Penelitian ini mengidentifikasi potensi kecurangan yang terdapat dalam proses pengelolaan keuangan desa. Potensi kecurangan diidentifikasi menggunakan teori segitiga kecurangan yakni tekanan, kesempatan dan rasionalisasi. Dari teori segitiga kecurangan tersebut selanjutnya dijabarkan menjadi indikator-indikator yang akan digunakan untuk mengidentifikasi setiap proses pengelolaan keuangan desa yang terdiri dari proses perencanaan, pelaksanaan, penatausahaan, pelaporan dan pertanggungjawaban.

Penelitian yang telah dilakukan mengenai potensi kecurangan dalam pengelolaan keuangan desa ini menyimpulkan bahwa pada Desa Kesongo,
Kecamatan Tuntang, Kabupaten Semarang terdapat potensi kecurangan dalam pengelolaan keuangan desa. Indikatorindikatornya adalah: pelaku kecurangan menganggap wajar atas kesalahan yang dilakukan dan sering mengulangi kesalahan tersebut; merasa tidak ada pihak yang dirugikan; keharusan untuk melakukan sesuatu; dan tindakan indisipliner. Selain itu, pengendalian yang baik diperlukan guna mencegah terjadinya potensi kecurangan dalam pengelolaan keuangan desa.

\section{Keterbatasan}

Topik penelitian yang cukup sensitif ini dapat menimbulkan hasil wawancara dari narasumber yang tidak mencerminkan keadaan yang sebenarnya. Objek penelitian masih sebatas aparat Desa Kesongo secara internal, belum melibatkan masyarakat desa dan lembaga yang lebih tinggi sebagai pihak eksternal pemerintahan Desa Kesongo.

\section{Saran}

Penelitian selanjutnya diharapkan peneliti untuk lebih melibatkan narasumber selain aparat desa untuk memberikan informasi yang sesuai dengan keadaan sebenarnya seperti masyarakat, inspektorat dan Aparat Pengawasan Intern Pemerintah (APIP).

\section{Implikasi}

Hasil dari penelitian ini dapat digunakan pemerintah desa untuk mengetahui potensi kecurangan dan mengidentifikasi mengenai tindakan kecurangan oleh aparat desa yang dapat terjadi pada pengelolaan keuangan desa. Penelitian ini juga dapat digunakan sebagai bahan evaluasi atas pengelolaan keuangan baik bagi Pemerintahan Desa Kesongo, masyarakat desa, lembaga lembaga terkait dan Badan Pengawasan Keuangan dan Pembangunan (BPKP) agar dapat memperkecil bahkan mencegah potensi kecurangan yang mungkin akan terjadi. 


\section{Daftar Pustaka}

Abidin, M. Z. (2015). Tinjauan Atas Pelaksanaan Keuangan Desa Dalam Mendukung Kebijakan Dana Desa. JUrnal Ekonomi \& Kebijakan Publik Vol. 6 No.1, 6176.

Albrecht et. al. (2012). Fraud Examination. USA: Chengange Learning.

Albrect, W. S., Albrect, C. C., Albrect, C. O., \& Zimbelman, M. F. (2011). Fraud Examination. USA: SouthWestern Cengage Learning.

Atmadja, A. T., \& Saputra, A. K. (2017). Pencegahan Fraud Dalam Pengelolaan Keuangan Desa. Jurnal Ilmiah Akuntansi dan Bisnis, Vol. 12.

Hehanussa, S. (2015). Pengaruh Penyajian Laporan Keuangan Daerah dan aksesibilitas Laporan Keuangan Daerah Terhadap Transparansi dan akuntabilitas Pengelolaan Keuangan Daerah Kota Ambon. Jurnal Unissula Vol. 2 No. 1, 8290.

Hooper, M. J., \& Pornelli, C. M. (2014, August 2). Deterring and detecting financial fraud: A platform for action. Retrieved from The Center for Audit Quality | AFFILIATED WITH THE AMERICAN INSTITUTE OF CPAS: http://www.thecaq.org/docs/report s-and-publications/deterring-anddetecting-financial-reportingfraud-a-platform-for-action.pdf?

ICW. (2018, February 5). Outlook Dana Desa $2018 \quad$ Potensi Penyalahgunaan Anggaran Desa di Tahun Politik. Retrieved from Antikorupsi | Indonesia Corruption Watch:

https://antikorupsi.org/id/news/outl ook-dana-desa-2018-potensipenyalahgunaan-anggaran-desa-ditahun-politik
Kelly, P., \& Hartley, C. A. (2010). Casino gambling and workplace fraud: a cautionary tale for managers. Management Research Review, 224-239.

Menteri Dalam Negeri Republik Indonesia. (2014). Permendagri No 113 Tahun 2014 Tentang Pengelolaan Keuangan Desa. Jakarta.

Putri, E., \& Wahyono. (2018). Pengaruh Moralitas Individu, Asimetri Informasi, Efektivitas Pengendalian Internal, dan Keadilan Organisasi Terhadap Kecenderungan Kecurangan (Fraud) Akuntansi (Studi Empiris pada Badan Usaha Milik Daerah Kota Surakarta). Jurnal Akuntansi Syariah Volume 1 Nomor 2, 233244.

Rahman, M. A., Suwandi, M., \& Hamid, A. (2016). Transparansi dan akuntabilitas pengelolaan keuangan alokasi dana desa (ADD) dalam pencapaian good governance (Studi Empiris di Kecamatan Bontomarannu Kabupaten Gowa). Jurnal Manajemen Ide Dan Inspirasi.

Ratmono, D., Diany, Y. A., \& Purwanto, A. (2017). DAPATKAH TEORI FRAUD TRIANGLE MENJELASKAN

KECURANGAN DALAM LAPORAN KEUANGAN? Jurnal Akuntansi dan Auditing Volume 14/No. 2, 100-117.

Sanjiwani. (2015). Akuntabilitas Pengelolaan Dana Desa (Studi Kasus Pengelolaan Alokasi Dana Desa di Kecamatan Kalisat Kanupaten Jember Tahun 2013). Jurnal Akuntansi Universitas Jember, 1-6.

Schuchter, A., \& Levi, M. (2016). The Fraud Triangle Revisited. Security Journal, 107-121.

Seputro, H. Y., Wahyuningsih, S. D., \& Sunrowiyati, S. (2017). Potensi 
Jurnal Akuntansi Maranathaø Volume 11 Nomor 2, November 2019 : 199-210

Fraud dan Strategi Anti Fraud Pengelolaan Keuangan Desa. Jurnal Penelitian Teori Dan Terapan Akuntansi, 79-93.

Tjahjono, S., \& dkk. (2013). Business Crimes And Ethics, Konsep Dan Studi Kasus Fraud Di Indonesia Dan Global. Yogyakarta: ANDI.

Udayani, F., \& Sari, R. (2017). Pengaruh Pengendalian Internal dan Moralitas Individu pada Kecenderungan Kecurangan Akuntansi. E-Jurnal Akuntansi Universitas Udayana Vol.18.3, 1774-1779.

Walukow, M. I., Kalangi, L., \& Piantik, S. (2017). Analisis perencanaan pengelolaan keuangan desa sesuai dengan Peraturan Menteri Dalam Negeri nomor 113 tahun 2014 di Desa Kauneran Kecamatan Sonder Kabupaten Minahasa. Jurnal Riset Akuntansi Going Concern, 266275.

Wells, J. T. (2011). Corporate Fraud Handbook: Prevention and Detection: 3rd Edition. Hoboken, New Jersey: John Wiley \& Sons Inc.

Yeni. (2011). Persepsi Mahasiswa Akuntansi Universitas Bina Nusantara Terhadap Fraudulent Financial. Tesis S1 Tidak Dipublikasikan, Universitas Bina Nusantara, Jakarta.

Yulianah, Y. (2015). Potensi penyelewengan alokasi dana desa dikaji menurut Peraturan Menteri Dalam Negeri nomor 37 tahun 2007 tentang pengelolaan keuangan desa. Jurnal Hukum Mimbar Justitia, 608-627. 